\title{
Gender Effects of Social Security Reform in Chile
}

\author{
Alejandra Cox Edwards
}

\begin{abstract}
In 1981 Chile replaced a mature government-run social security system that operated on a pay-as-you-go basis with a privately managed system based on individual retirement accounts. The new system is more fiscally sustainable because pension benefits are defined by contributions. The minimum pension guaranteed to beneficiaries with at least 20 years is funded from general taxes, preserving the tight matching between contributions and benefits. The new system also eliminates several cross-subsidies. Men and women with less than secondary education gain under the new system, but single women with more education lose. Comparison of the old and the new systems reveals a complex set of factors that cause gender effects given constant behavior or change behavior across genders.
\end{abstract}

\section{Chile's Social Security System}

By the late 1970s Chile's social security system had generated a large deficit despite several hikes in payroll taxes. In 1979 pension ages were raised to put the system in balance (Wagner 1983). In 1981 Chile replaced the mature government-run social security system, which operated on a pay-as-you-go basis, with a privately managed system based on individual retirement accounts. The new system is more fiscally sustainable than the old system, with contribution-defined pension benefits. The reformed system includes a minimum pension guarantee, which is funded from the general government budget, preserving the tight link between contributions and benefits of the pension funds. The reformed system also insures contributors against the risk of loosing their income-generating capacity before retirement age by including an explicit insurance premium covering the risks of disability and early death.

From the point of view of macroeconomic aggregates, the Chilean social security system-managed mostly by private companies, Administradoras de

Alejandra Cox Edwards is in the Department of Economics at California State University, Long Beach. Her e-mail address is edwards.ac@attbi.com. This article draws heavily on two reports prepared for Gender and Social Security, a World Bank research project managed by Estelle James (World Bank Institute) and Maria Correia (Latin America and the Caribbean Region Gender Team). The author is grateful to Estelle James, Salvador Valdes, anonymous referees, and seminar participants at Centro de Estudios Públicos, Santiago, Chile, for their comments and suggestions and to the Economics Department at Universidad de Chile, particularly Dante Contreras, for assistance with the CASEN data.

DOI: $10.1093 /$ wber/lhf002

(C) 2002 The International Bank for Reconstruction and Development / THE WORLD BANK 
Fondos de Pensiones-can have annual surpluses or deficits. The long-term viability of the system is protected by the direct link between contributions and benefits. From the individual's perspective, social security contributions have become a form of delayed compensation because all parts of the contribution have a counterpart in paid benefits. ${ }^{1}$ This change in design represents a reduction in the payroll tax. In addition, the reform reduced the payroll tax rate earmarked to finance pensions and health insurance from about 30 percent to 20 percent of taxable earnings. ${ }^{2}$

Social security systems have particular ways of dealing with intrafamily distribution of incomes and old-age benefits. To address these differences, this study estimates individual contributions and benefits before and after reform. The focus is on gender differences in contributions and old-age benefits; other social security benefits (such as disability and premature death) are left out of the comparison. I examine the effects of four changes:

1. Workers who contributed for less than 10 years received no pensions under the old system. Under the new system everyone who has contributed to the system receives a pension, in proportion to his or her fund accumulation. This change is particularly significant for women, who tend to have low levels of attachment to the labor force.

2. In the old system, pension benefits were determined by a formula that multiplied the average contributory income of the last five years of work by the number of years of contributions, rewarding a long-term commitment to the labor market. In the new system, pensions are a function of the accumulation of funds through compound interest, giving a heavier weight to contributions made early in life. This change favors women as well as men who have career interruptions or relatively flat age-earnings profiles throughout their careers.

3. Unlike the old system, in which survivor's pensions were funded from systemwide contributions, the new system is based on joint annuities. That is, the pension benefits of the principal are based on the pensioner's fund accumulation, net of a reserve to fund his or her survivor's benefits. This change internalizes the accumulation of pension funds at the family level,

1. The system is still perceived as a tax by people whose desired savings rate is below the implicit rate imposed by social security. Edwards and Edwards (2002) estimate the tax component of the Chilean payroll contribution toward social security.

2. The old system was financed by a payroll tax, with a relatively weak link between contributions and benefits. In 1973, for example, contributions to the retirement plan by employers and employees averaged 26 percent of earnings. Once contributions to the national health system were included, total payroll contributions exceeded 50 percent of earnings for some workers. During the late 1970s payroll tax rates were lowered; in 1980 social security contributions claimed 32.50-41.04 percent of taxable earnings. The new system reduced the overall contribution to social security (pension, health, and other forms of insurance) to about 20 percent of taxable earnings, established a set of common rules for all contributors, compartmentalized the various parts of the social security package in different products, and introduced competitive forces in the market for these products. 
increasing the marginal benefit to the family of every peso put into the system.

4. In the old system's main program, widows were required to choose between survivor's benefits and their own retirement benefits. This rule reduced the marginal value of their own contributions, making the payroll tax even higher for married women. Under the new system, benefits can be combined, improving work incentives for married women.

These four changes have raised the marginal benefit of own contributions for all, particularly for those whose contributions were insufficient to qualify for benefits. Furthermore, the new system guarantees a minimum pension to people who contribute at least 20 years and whose fund accumulation provides for an annuity below the minimum pension. This represents an additional incentive for participation, although it also acts as a disincentive to participate and contribute once a person with relatively low contributions has accumulated 20 years in the system.

The current living standards of the elderly population are the product of both a traditional system of extended family arrangements and a social security system that proved to be unsustainable and was therefore fully reformed. In urban areas the proportion of elderly men who receive an old-age pensions (62 percent) is twice that of elderly women ( 31 percent). Another 19 percent of elderly women receive survivor's pensions, closing the retirement income gender gap. In rural areas, where old-age pensions are less typical, more than 23 percent of elderly women are beneficiaries of pensión asistencial (PASIS), a government program targeting the elderly poor that operates outside of the social security system funding. In urban and rural areas older women are more likely than men of the same age group to be widowed and to live in extended households (Edwards 2000).

Future living standards for elderly women will depend on living arrangements, the coverage of the PASIS program or its equivalent, and the pension system. Future pension benefits for women are determined by two main sources: their own accumulated funds and survivor benefits for married women. As schooling levels have risen in Chile, marriage age has been delayed and labor force participation rates have increased. The fraction of women qualifying for pension benefits is therefore likely to increase.

Women who work for pay typically accumulate pension funds at a significantly lower pace than men for two reasons. First, women are more likely than men to interrupt their careers (to take care of children, the sick, or elderly parents or in-laws). As a result, the density of labor market participation throughout the life cycle is lower for women than for men. Second, women's salaries are generally lower than men's, even after controlling for age and schooling. The already slower accumulation is often stopped at a younger age, given that the social security system allows women to collect pensions at age 60 , whereas men must wait until age 65 . At age 60 women are expected to live 23 more years, a long stretch for the accumulated funds. However, the present value of expected 
old-age benefits of a married woman is above the level of accumulated funds because of the likelihood that she will survive her husband, whose pension she will receive.

\section{Data And Methodology}

The key data source for the analysis is the micro data set of the Caracterizacion Socioeconómica Nacional (CASEN) for 1994, a national household survey carried by the National Planning Office. This survey collects information on a variety of indicators, including demographic characteristics, labor force participation, earnings, affiliation to social security, and the answer to the question "Are you a contributor to any of the social security systems?"

CASEN is a reliable source for estimating the socioeconomic characteristics of the population. The other source of information on affiliates and contributors is the Superintendencia de Administradoras de Fondos de Pensiones (SAFP), to which all private Administradoras de Fondos de Pensiones provide information on their accounts. The SAFP publishes aggregate data and does not provide researchers with individual-level data. According to SAFP data, the ratio of contributors to affiliates fell from 58 percent in 1985 to 49 percent in 1994 and to 44 percent in 2000 . This decline is driven by the fact that affiliation is a forever classification. People who join the labor force and make contributions for a short time and then do not return to the labor force remain affiliated with the system, even though they may forget that they belong to it. Even if people leave the country, they remain in the SAFP counts. ${ }^{3}$

Unfortunately, information on years of contributions is not available from CASEN or publicly available from the SAFPs. This article uses the cross-section data to build a series of synthetic cohorts and use them to project life-cycle earnings and contributions of "typical" people. The methodology consists of defining key observed individual characteristics and measuring employment patterns by age, leading to the construction of synthetic cohorts from the cross-section.

The cross-section data allow us to estimate the labor force participation rate for a typical woman of a given age. The observed participation patterns can be used to project the behavior of a 20-year-old into the future, assuming that the behavior of the observed 30-, 40-, and 50-year-olds is characteristic of all women. Young women today are unlikely to behave as their predecessors did, however, particularly regarding labor force participation. The key factor driving this generational change is that the younger cohorts have more schooling. Thus unless one controls for schooling, a synthetic cohort built from cross-section data would introduce an error in the link between age and labor force participation.

3. As an anonymous referee pointed out, the proportion of contributors to affiliates based on CASEN data is 55 percent for the national data -6 points above the SAFP estimate. I do not believe this difference invalidates the methodology. Although CASEN excludes affiliates who have left the country or forgotten their affiliation, its estimate is still representative of typical working affiliates. 
After carefully studying the links between labor force participation and schooling, I divided the 1994 urban sample by gender and into five schooling categories: incomplete primary, incomplete secondary, complete secondary, up to four years of postsecondary, and more than four years of postsecondary. The assumption is that each of these schooling groups has a common pattern of labor force participation and that the pattern is stable over time. If the average rate of employment over a period is used to estimate the number of months of work, the implicit assumption is that all people in the sample base work some of the time. This assumption is appropriate for the men's cases, because it is known (from cohort data) that practically all men have been in the labor force for some time by age 30 (Edwards 2001). However, evidence from recent cohorts suggests that no more than 95 percent of women with postsecondary schooling join the labor force at some point, and this fraction falls to 80 percent and 75 percent for females with less schooling. Therefore, this procedure would underestimate the number of months of work for the "appropriate" sample of women.

Information on affiliation is very useful because affiliated men and women are known to have been in the labor force at some point. This variable allows us to separate men and women into two subgroups: people who are affiliated with the system and make contributions toward pensions at least some of the time and the unaffiliated. Naturally, participation rates are higher among women affiliated with the social security system relative to all women. Given our goal of estimating social security contributions and benefits, the methodology rests on estimates for women affiliated with the social security system by schooling and marital status.

Final values of accumulated contributions are a function of the system's rate of return and individual retirement ages. Individual pension benefits estimated from the accumulated funds depend on survival probabilities at pension age. Estimated individual benefits are subsequently compared with what the same "typical" people would have obtained using the nominal formula of the old system. These comparisons allow us to better understand the gender effects of social security reform.

\section{Employment and Social Security Participation by Gender}

Labor force participants are a subsample of working-age people with distinct gender, age, schooling, and marital status characteristics. Labor force participation of 16- to 65-year-old urban women and men is driven by marital status, years since finishing school or potential experience, and postsecondary schooling. Participation is significantly lower for women (39 percent) than for men (82 percent). Marriage further reduces the probability of participation for women and increases it for men. Postsecondary schooling increases the likelihood of participation and diminishes the negative effect of marriage for women but lowers the probability of participation for men. 


\section{Who Is Required to Affiliate and Who Contributes to Social Security?}

Chilean law requires formal employees to make contributions to their retirement accounts, and allows the self-employed to make voluntary contributions to the pension system. ${ }^{4}$ Affiliation is necessary to contribute to the system and to obtain benefits, and once a person affiliates to the system, he or she remains affiliated for life. In 1994, 67 percent of men and 39 percent of women in the workingage population were affiliated with the system. Affiliates have a higher than average attachment to the labor force. About 82 percent of male affiliates and 64 percent of women affiliates were working at the time of the survey-higher percentages than the 72 percent of men and 36 percent of women working in the total working-age population.

Unlike social security affiliation, work status is not set for life. Many people become self-employed after working as employees or move back and forth between the two categories. It is therefore not surprising that a significant fraction of workers classified as self-employed make contributions to social security. In 1994 about 25 percent of people who were not required to contribute (the selfemployed and employees without contracts) did so. The fraction of self-employed people who make contributions increases with age and schooling. Contributing does not vary much with the level of salary or the sector of employment, but establishment size and gender are important factors. In particular, workers in larger establishments are more likely to contribute. With or without controlling for industry and establishment size, self-employed women are 6.2 percent less likely to contribute than self-employed males. ${ }^{5}$

This study estimates working patterns of people affiliated with the social security system and assume that month-to-month contributions by affiliates are driven primarily by whether they are working in a given month. In fact we know that more than 90 percent of men and women affiliates who were working at the time of the survey contribute toward social security. There is a remarkable similarity across genders in contributory status, as long as the sample is limited to affiliated individuals. Among men and women with less than primary schooling, 84 percent contributed in 1994. Contribution rates rose to 89 percent among those with incomplete primary, to 93 percent among those with complete secondary and men with up to four years of postsecondary education, and to 96 percent for women with postsecondary and men with five or more years of postsecondary education.

4. Formality is established by a written contract that employers and employees are required to sign.

5. This finding suggests that in similar circumstances to men, women are less likely to assign a marginal value to their social security contributions. There are two possible explanations. First, there may be a relatively larger fraction of women who work for pay in a given period who are not planning to work for pay for any significant length of time. The fact that married women obtain health care coverage through a contributing husband's family plan may also be part of the explanation. This reduces the value of the 20 percent contribution to about 13 percent. Further research should examine the impact of the tied-in character of the pension and health care programs on a married couple's incentive to save toward retirement. 


\section{Estimating Years of Contributions}

The probability of employment varies by schooling, marital status, and gender. The sample of affiliates is divided into 20 main categories based on these three variables. Within each of these categories, I calculate the fraction of men and women that work at every age. I then assume that the typical man or woman within each schooling category works as a typical single person until marriage and as a married person afterward. The marriage age for the typical man and woman is defined as the age at which 50 percent of the corresponding category is married. Marriage tends to be earlier for men affiliates than for men as a whole, and marriage tends to be delayed for women affiliates compared with the women as a whole. Because I am focused on affiliates, I use the corresponding marriage ages for that sample. This step reduces the 20 categories to 10,5 schooling categories and 2 genders. The average fraction of workers is used to estimate the "fraction of the time that typical individuals work at every age." The results of this estimation are summarized in table 1 and expressed in estimated years of work by age category.

Assuming that working affiliates make contributions to social security, the emerging relation between age and years of contributions is captured in figure 1 . A higher line in figure 1 indicates steady accumulation of contributions over many years, as is the case for men with secondary schooling. A relatively high and steep line indicates rapid accumulation after a later start, as is the case for men and women with five or more years of postsecondary schooling. A lower and flatter line shows a lower degree of labor force attachment and a relatively slower accumulation of contributions, as is the case with women with secondary schooling.

Gender differences in the degree of attachment to the labor force among affiliates result in important differences in estimated lifetime contributions. Men typically accumulate 40 years' worth of contributions between age 16 and 65 . Women, especially women in the lower schooling categories, tend to have more interruptions. As a result, on average women who complete secondary schooling accumulate less than 30 years' worth of contributions by age 65 .

\section{Earnings Profiles}

To estimate the accumulation of funds, I use the estimates of contributory behavior-obtained in the previous subsection-and earnings. I produce an estimate of monthly wages by age, based on observed earnings by age, sex, and schooling. The sample includes all workers in an attempt to keep it as large as possible. This is appropriate because wage levels do not significantly affect affiliation and contribution behavior. Thus earnings estimates originating from a broad sample of workers should not differ from estimates originating from a sample of ever working affiliates.

I start from the assumption that current patterns of earnings (as a function of schooling and experience) have persisted for some time and will remain stable in the future. The key challenge is to capture the earnings pattern from the exist- 
TABle 1. Estimated Years of Contributions, by Age and Schooling

\begin{tabular}{lccccc}
\hline $\begin{array}{l}\text { Age } \\
\text { category }\end{array}$ & $\begin{array}{c}\text { Incomplete } \\
\text { primary }\end{array}$ & $\begin{array}{c}\text { Incomplete } \\
\text { secondary }\end{array}$ & $\begin{array}{c}\text { Complete } \\
\text { secondary }\end{array}$ & $\begin{array}{c}\text { Up to 4 years } \\
\text { postsecondary }\end{array}$ & $\begin{array}{c}\text { More than 4 years } \\
\text { postsecondary }\end{array}$ \\
\hline $\begin{array}{l}\text { Ever working } \\
\text { male affiliates }\end{array}$ & & & & \\
$16-20$ & 3.37 & 3.02 & 1.65 & 1.28 & 0.00 \\
$21-25$ & 7.02 & 6.91 & 5.84 & 5.35 & 2.79 \\
$26-30$ & 10.65 & 11.04 & 10.33 & 9.77 & 7.25 \\
$31-35$ & 14.49 & 15.33 & 15.03 & 14.47 & 12.12 \\
$36-40$ & 18.46 & 19.63 & 19.72 & 19.09 & 21.77 \\
$41-45$ & 22.86 & 23.98 & 24.25 & 23.56 & 26.48 \\
$46-50$ & 26.75 & 28.22 & 28.37 & 27.79 & 31.25 \\
$51-55$ & 30.49 & 32.42 & 32.34 & 31.80 & 38.91 \\
$56-60$ & 33.52 & 35.74 & 36.04 & 35.63 & \\
$61-65$ & 35.98 & 38.05 & 38.29 & 38.97 & 3.00 \\
Ever working & female affiliates & & & & 7.87 \\
$16-20$ & 3.64 & 2.85 & 1.39 & 1.21 & 12.10 \\
$21-25$ & 6.84 & 6.51 & 5.31 & 5.12 & 21.53 \\
$26-30$ & 9.80 & 10.03 & 8.64 & 8.90 & 26.18 \\
$31-35$ & 11.44 & 11.95 & 11.58 & 12.64 & 30.81 \\
$36-40$ & 13.79 & 14.78 & 14.95 & 16.35 & 34.77 \\
$41-45$ & 16.23 & 17.69 & 18.32 & 20.72 & 36.05 \\
$46-50$ & 18.32 & 19.90 & 21.70 & 24.08 & \\
$51-55$ & 20.86 & 22.21 & 24.17 & 28.52 & 32.68 \\
$56-60$ & 22.49 & 24.06 & 26.55 & 32.92 & \\
$61-65$ & 23.42 & 24.17 & 26.80 & & \\
\hline
\end{tabular}

Note: Data are for urban areas only.

Source: Author's estimates based on CASEN 94 data.

ing data. The human capital earnings function, in which earnings are expressed as a quadratic in potential experience, is probably the most widely accepted empirical specification in economics. This procedure is not the most appropriate here, however, because I lack a good proxy for female experience and my aim is to get the best estimate of earnings for workers of a given age (because contributions and benefits eligibility are bound by age). I therefore use an alternative procedure to compute earnings.

I organize the data on earnings from the 1994 CASEN survey by sex, age, and schooling and calculate an average income for each cell (table 2). This method does not impose a particular functional form, and it has the advantage of implicitly weighting the sample according to its composition (by other characteristics) within each cell. Given the limitation imposed by sample sizes, it is not possible to estimate average earnings for single-age categories. A five-year interval was chosen to increase sample size while keeping the age categories narrow, because estimated salaries for a range of years are likely to overestimate starting-period contributions and underestimate end-period contributions.

The resulting earnings-experience profiles have a concave shape: Earnings grow fastest at the earlier stage of most groups' careers, earnings growth slows after age 40 , and earnings often fall bellow the peak by age 60 . Estimated gender in- 
Figure 1. Estimated Years of Contribution by Age, Schooling, and Gender

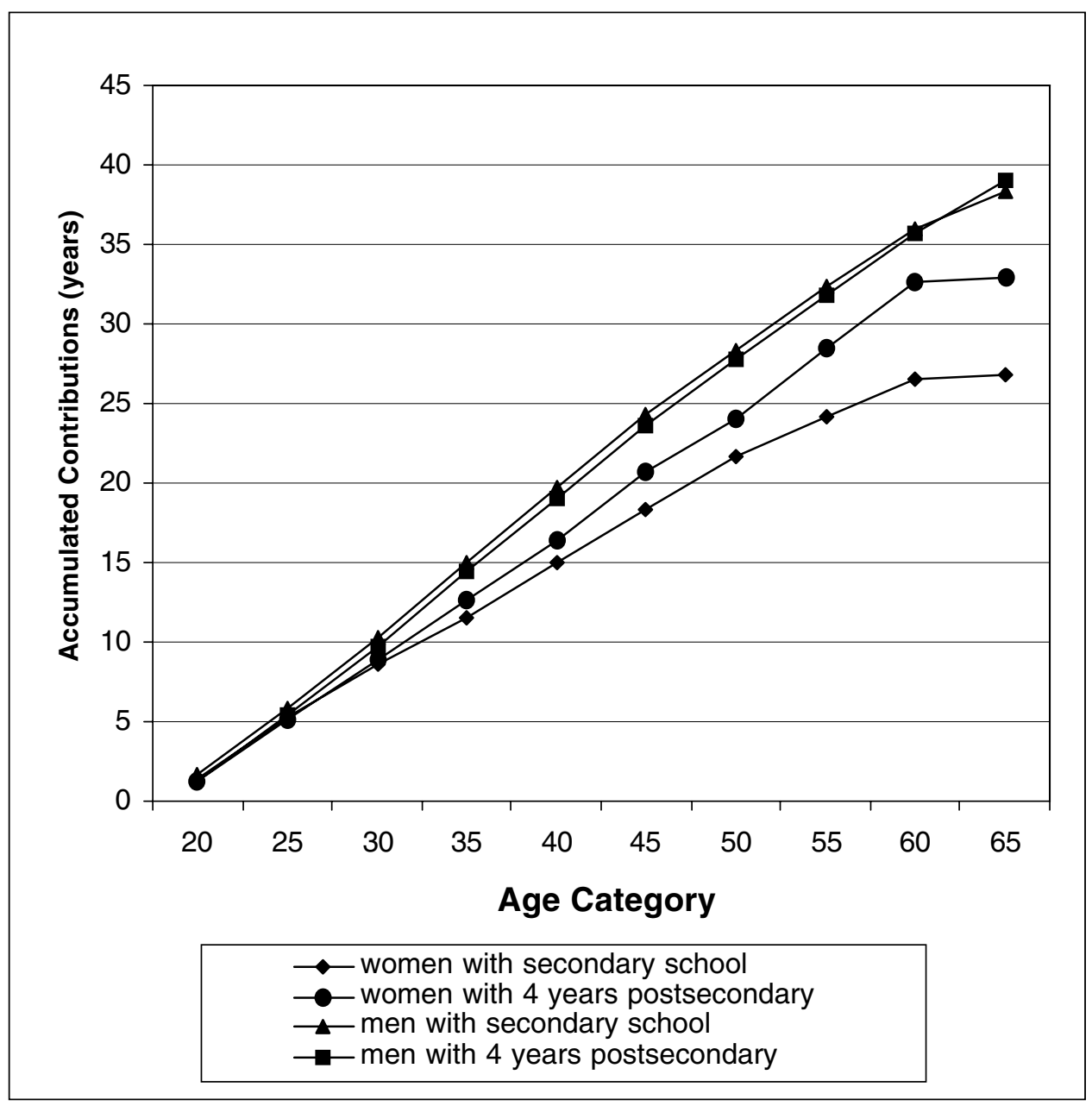

Source: Table 1.

come differentials by schooling and age indicate that the female-to-male income ratio is $0.6-0.8$ in most cases. The notable exception is people with five or more years of schooling, among whom the differential is closer to 0.5. The income differential grows sharply between ages 45 and 50 and then declines again, a feature that affects savings accumulation toward pensions.

\section{Fund Accumulation and the Effect of Gender on Pensions}

This section explores the effect of gender on the accumulation of pension funds, pension benefits, and replacement rates, based on simulations for representa- 
TABle 2. Average Income, by Age and Schooling (1994 pesos, except where otherwise indicated)

\begin{tabular}{|c|c|c|c|c|c|}
\hline $\begin{array}{l}\text { Age } \\
\text { category }\end{array}$ & $\begin{array}{l}\text { Incomplete } \\
\text { primary }\end{array}$ & $\begin{array}{l}\text { Incomplete } \\
\text { secondary }\end{array}$ & $\begin{array}{l}\text { Complete } \\
\text { secondary }\end{array}$ & $\begin{array}{l}\text { Up to } 4 \text { years } \\
\text { postsecondary }\end{array}$ & $\begin{array}{c}\text { More than } 4 \text { years } \\
\text { postsecondary }\end{array}$ \\
\hline \multicolumn{6}{|c|}{ Estimated monthly male earnings } \\
\hline $16-20$ & 49,145 & 61,958 & 72,894 & 76,149 & n.a. \\
\hline $21-25$ & 61,366 & 72,884 & 89,050 & 119,020 & 313,293 \\
\hline $26-30$ & 67,259 & 84,219 & 108,092 & 155,493 & 358,164 \\
\hline $31-35$ & 70,030 & 94,988 & 133,436 & 195,497 & 482,094 \\
\hline $36-40$ & 76,019 & 103,699 & 151,606 & 223,750 & 524,083 \\
\hline $41-45$ & 88,323 & 115,844 & 174,791 & 248,305 & 540,316 \\
\hline $46-50$ & 93,893 & 143,450 & 221,171 & 269,793 & 643,224 \\
\hline $51-55$ & 90,986 & 128,078 & 201,733 & 247,731 & 595,663 \\
\hline $56-60$ & 92,653 & 135,883 & 197,906 & 281,721 & 542,736 \\
\hline $61-65$ & 81,430 & 122,726 & 161,457 & 240,541 & 513,568 \\
\hline \multicolumn{6}{|c|}{ Estimated monthly female earnings } \\
\hline $16-20$ & 48,479 & 48,124 & 62,718 & 66,393 & n.a. \\
\hline $21-25$ & 49,496 & 60,800 & 75,702 & 95,447 & 179,198 \\
\hline $26-30$ & 53,374 & 59,136 & 82,812 & 167,499 & 232,048 \\
\hline $31-35$ & 53,044 & 66,317 & 91,003 & 130,258 & 260,202 \\
\hline $36-40$ & 52,251 & 70,051 & 107,584 & 138,252 & 304,915 \\
\hline $41-45$ & 58,110 & 79,232 & 137,248 & 179,873 & 312,696 \\
\hline $46-50$ & 60,745 & 83,353 & 134,975 & 209,027 & 212,333 \\
\hline $51-55$ & 62,959 & 75,782 & 156,673 & 154,783 & 222,027 \\
\hline $56-60$ & 63,795 & 93,730 & 168,694 & 149,990 & 283,680 \\
\hline $61-65$ & 58,703 & 62,813 & 116,958 & 157,500 & 365,000 \\
\hline
\end{tabular}

n.a. = Not applicable.

Note: Data are for urban areas only and are based on full-time earners.

Source: Author's estimates based on CASEN 94 data.

tive workers. The impact of the change from a pay-as-you-go to a multipillar system and of particular pay-out policies of a defined-contributions system is calculated.

\section{Gender Differences in Fund Accumulation}

I assume that workers in a given schooling and gender category contribute 10 percent of their income, as required by law. Earnings for each age are assumed to be equal to the estimated value for the corresponding five-year age period. In some simulations I add a secular growth to earnings, increasing the estimated annual wage by the corresponding growth effect. For a given age, estimated annual months of contributions are equal to 12 times accumulated contributions for the five-year period divided by 5 . The accumulation of funds is the result of compounding the estimated contributions at various interest rates.

According to these estimates, women accumulate funds at a lower pace and have income profiles that are flatter and lower than those of men. The estimates 
presented are to be used as a benchmark; the system's rates of return as well as the affiliate's income and number of years of accumulation relative to the mean affect these figures. Given the same estimated earnings, the higher the rate of return, the larger the accumulated fund. The longer a person works, the higher the annuity, with benefits falling more than proportionally if a person works less than the 20 years required to qualify for the minimum pension. (For a broader set of estimates, see Edwards 2001.)

The calculations in table 3 show estimated lifetime accumulation of funds for men and women by level of schooling. Estimates based on a 5 percent rate of return and a 2 percent income growth generate women's accumulations that are 36-52 percent of men's. At the bottom of the table, I decompose the difference in fund accumulations within each schooling category in four steps:

1. If women postpone retirement to age 65 , the gap between men and women would narrow by 10-15 percent depending on the level of schooling. This effect tends to be larger for more educated women because their work intensity from age 60 to 65 tends to be higher.

2. If women continue to work only to age 60 but do so with the same work intensity of men, their pension funds would increase 1-19 percent, depending on the level of schooling. This effect varies significantly across schooling groups, because there is a significant variation in work intensity among women by schooling group, with highly educated women working almost as intensively as men with the same level of education.

3. If women work to age 60 and do not change their work patterns but are paid the same as men, the pension fund gap between men and women would narrow by 7-25 percentage points, depending on the schooling group. The gap would narrow 7 percent among people with secondary education and up to four years of postsecondary education, by about 13 percent for the lower education groups, and by more than 25 percent for people with the highest level of schooling. One reason for the larger effect of income increases for women in the highest schooling group is that this is the group with the most labor market attachment. An increase in income levels is thus weighted by a higher number than an increase in earnings of other groups of women.

4. The last step calculates the effects of the interaction of the first three effects.

\section{Estimated Future Pension Benefits}

The combination of earlier retirement age and longer life expectancy means that women need to provide for 23 years of income from their accumulated funds. Married men retire at age 65 and must provide for a joint annuity of 21 years. This joint annuity is composed of 15 years of own pension and 6 years of widow's pension, at 60 percent of own benefit. Single men retire at age 65 and must provide for their own 15 years' annuity. Therefore, even if men and women started with the same fund accumulation at their "normal" retirement age, a woman's 


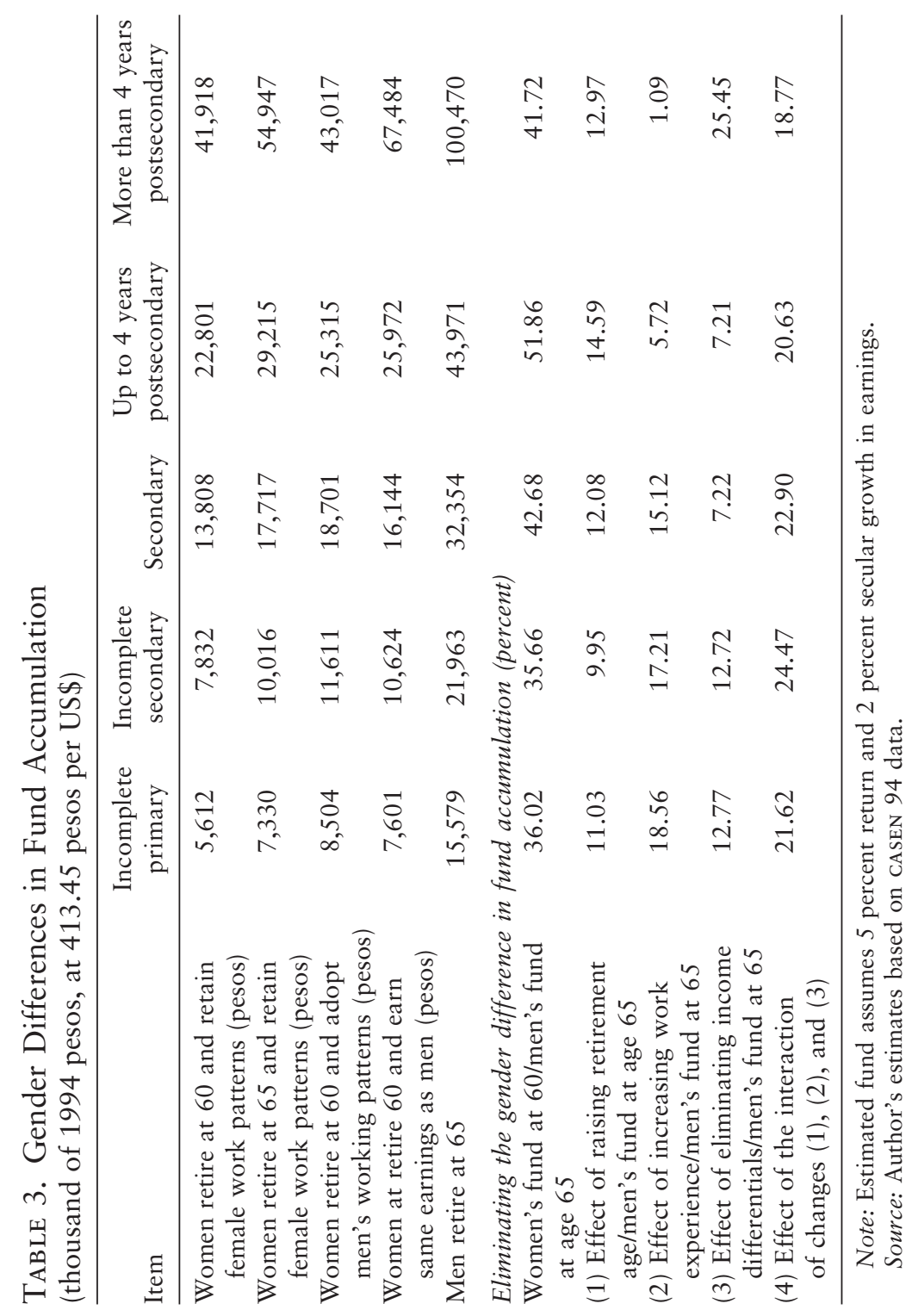


annuity derived exclusively from her accumulated funds would be necessarily smaller than that of a man derived from his accumulated fund.

To calculate the annuities from the estimated fund, I assume that the typical man is married to a woman three years younger than he is (this assumption is consistent with CASEN data). This man retires at age 65 with a life expectancy of 15 years. Because his wife is expected to survive him by six years he is required to provide for six years of survivor's pension, at 60 percent of his own pension. Chilean law requires retiring married men to put aside funds to cover pensions for their widows and surviving children (the amount required to comply with this regulation is determined through a private contract between the retiree and an insurance company). The law does not require retiring married women to provide for their surviving husbands, unless the husband is handicapped. I assume that there are no surviving minors, that men reserve part of their funds to provide for their widows, and that women convert their entire fund to an annuity. I also assume that insurance companies are allowed to use different survival tables for men and women. If the resulting annuity is smaller than the minimum pension guarantee, the estimated value is increased to the minimum pension.

Based on the calculated annuity, women's replacement ratios (the estimated annuity divided by the reference salary) are almost 60 percent of men's. These differences in replacement rates are smaller than the measured differences in the accumulated funds and the annuities, however, for three reasons. First, several categories of women qualify for the minimum pension, which raises the annuity above the level supported by own funds. Second, replacement ratios are calculated as the ratio of the monthly annuity over the reference salary, which is the average tax base of the last 10 calendar years of work divided by 12 . The reference period corresponds to 120 calendar months. To the extent that the typical man or women works less than 120 calendar months during the reference period, the estimated reference salary is lower than the estimated average income for the same reference period. During the 10 years that precede the minimum pensionable age, women have an average work accumulation that is significantly lower than that of men. This causes the gender differential in reference earnings to be larger than the gender differential in earnings. Third, if the denominator in women's replacement ratio is relatively low, the resulting replacement ratio for women is relatively high.

\section{The Issue of Retirement Age}

A significant fraction of men and women who have reached retirement age choose not to claim benefits. Thus the retirement age operates as an option that people take when it is convenient for them. If women remain in the labor force beyond age 60 , they can add to their fund accumulation, and they are more likely to qualify for the minimum pension on the grounds of years of contributions. The impact on annuities is positive because the accumulated fund is larger and the number of years to be covered by the annuity is smaller. 
Under the low-returns scenario, women with less than complete secondary schooling have no gains from delaying claims because they qualify for the minimum pension guarantee. In contrast, women who complete secondary schooling stand to increase their annuity by 10 percent if they postpone claims, and women with higher levels of schooling stand to gain much more. Under the highreturns scenario, postponing claims increases the annuity about 50 percent for all groups. Whether an additional year of work past age 60 increases or decreases these women's welfare depends on individual preferences. One can say only that allowing people to draw a pension early or late is a superior alternative to imposing an age requirement before claiming benefits or forcing retirement at a given age.

\section{The Impact of Reform}

Under the old pension system rules, the monthly retirement benefit was equal to zero if the affiliate made less than 10 years' worth of contributions or the maximum of

$$
0.50 B S+0.01 B S(W-500) / 50 \text { or } 0.70 B S
$$

where $B S$ (the base salary) equals the sum of total taxable earnings of the previous five years divided by 60, indexing the last three years, and $W$ equals the total number of weeks of accumulated experience (beyond 520). ${ }^{6}$ Men could retire at age 65 and women at 60. (In 1979, the retirement age for women was raised from age 55 to 60 in an effort to contain the system's growing deficit.) Benefits included survivor's pensions equivalent to 50 percent of the pension of the originator for widows and 20 percent of the mean salary per child. Men typically work 40 years, and a man with 40 years of contributions was very close to the maximum replacement rate of 70 percent. Therefore, men's pensions and widow's pensions were generally capped.

Women with more than 10 years of contributions got a very good deal under the old system rules. They could retire 5 years earlier than men, receive a benefit based on their last 5 years of earnings, and receive a 60 percent replacement rate based on a typical life time experience of just 20-30 years of work. Women with less than 10 years of contributions faced no incentive to participate in the system because they did not qualify for benefits.

The deal was not so good for married women. Under the rules of the old social security system, which covered the majority of the currently retired population, women had to choose between retirement income and pension. That is, if they were eligible for benefits from their own working years and were also eligible for a widow's pension, they could not receive both two sets of benefits and had to choose the better of the two. ${ }^{7}$

6. Because rules vary across funds, I used the social security system rules. The social security system represented more than 60 percent of contributors in 1980.

7. Art. 7, Law 10.383 
Under the rules of the new social security system, benefits are a function of the accumulation of funds. There is no minimum number of years of contributions required to obtain a pension, as there was in the old system, which required at least 10 years. Contributions accrue to the accumulated fund independently of the timing of labor force participation and independently of the periodicity of income-generating activities. In fact, women who make contributions early in their careers get credit for the compound interest associated with those early contributions.

On the one hand, the new system pays benefits as a function of contributions, which tends to lower some women's benefits and raise the benefits of single men to the extent that they are not subject to a maximum benefit. On the other hand, the new system includes a minimum pension guaranteed, which raises the benefits for women with low levels of schooling significantly above the actuarially fair levels. Moreover, a married man is required to fund his wife's pension as a function of her probability of survival, lowering the benefits of married men relative to single men.

Table 4 provides estimates of social security-related incomes for elderly men and women in each of the schooling categories. To estimate widows' pensions, I assume that married couples belong to the same schooling category. ${ }^{8}$ The calculations highlight the complex effects of the system's reform. In particular, they suggest systematic effects by marital status and level of schooling. The calculations at the bottom of table 4 assume full indexation. However, because the old system was not fully indexed, the benefit estimates for the old system represent an upper bound. To give an idea of the degree of overestimation of these benefits, the following calculation is of interest. If benefits are maintained at the nominal level shown in table 4 and there is a 10 percent annual inflation, in the absence of indexation real benefits fall to less than 50 percent of their initial value after 10 years, to less than 20 percent after 17 years, and to a little more than 10 percent after 23 years.

Direct comparisons of benefits before and after reform do not take into account the degree of sustainability of the systems, in particular the fact that the old system was unable to deliver the promised benefits under its formulas. They

8. These estimates can be compared with those provided by Baeza Valdés and Burger Torres (1995), whose estimates are based on actual retirement cases. Using a sample of 4,064 people who retired under the new system, they estimate that the average replacement rate is 78 percent. The highest (relative) pensions were obtained by people who opted for early retirement, with a replacement rate of 82 percent under programmed retirement. Baeza Valdés and Burger Torres attribute this result to the fact that only those who enjoyed rapid accumulation of funds-mostly by making voluntary contributions-can opt for early retirement. Through December 1997 average old-age pensions under the capitalization system were 39 percent higher than average pensions under the old pay-as-you-go regime. Disability pensions under the new system were 61 percent higher than under the previous regime. Overall, replacement rates have been high-indeed, higher than in most industrial countries (see Davis 1998 and Gruber and Wise 1999). Naturally, because the Chilean system is a defined-contribution system, there are no assurances that the replacement rates observed until now will be maintained in the future. 
Table 4. Estimated Retirement Incomes under Old and New Systems (1994 pesos/month)

\begin{tabular}{|c|c|c|c|c|c|}
\hline & $\begin{array}{l}\text { Incomplete } \\
\text { primary }\end{array}$ & $\begin{array}{l}\text { Incomplete } \\
\text { secondary }\end{array}$ & Secondary & $\begin{array}{l}\text { Up to } 4 \text { years } \\
\text { postsecondary }\end{array}$ & $\begin{array}{c}\text { More than } \\
4 \text { years } \\
\text { postsecondary }\end{array}$ \\
\hline \multicolumn{6}{|c|}{ Married men, retiring at 65} \\
\hline New system & 97,917 & 138,043 & 203,356 & 276,368 & 631,482 \\
\hline Old system ${ }^{a}$ & 86,775 & 136,776 & 214,990 & 335,491 & 764,117 \\
\hline \multicolumn{6}{|l|}{ Women, new system } \\
\hline $\begin{array}{l}\text { Own pension adjusted } \\
\text { for minimum pension } \\
\text { age } 60-77^{\mathrm{b}}\end{array}$ & 37,738 & 43,679 & 77,010 & 127,169 & 233,788 \\
\hline $\begin{array}{l}\text { Widow's pension, } \\
\text { age } 78-83\end{array}$ & 64,331 & 90,693 & 133,604 & 181,571 & 414,880 \\
\hline $\begin{array}{l}\text { Own and widow's } \\
\text { pension, age } 78-83^{c}\end{array}$ & 64,331 & 133,995 & 209,950 & 307,642 & 646,650 \\
\hline \multicolumn{6}{|l|}{ Old system } \\
\hline $\begin{array}{l}\text { Own pension, working } \\
\text { women age } 60-77 \mathrm{~d}\end{array}$ & 28,508 & 48,661 & 116,798 & 185,780 & 333,517 \\
\hline $\begin{array}{l}\text { Widow's pension, } \\
\text { age } 78-83\end{array}$ & 43,388 & 68,388 & 107,495 & 167,746 & 382,059 \\
\hline $\begin{array}{l}\text { Own or widow's } \\
\text { pension, age } 78-83\end{array}$ & 43,388 & 68,388 & 116,798 & 185,780 & 382,059 \\
\hline
\end{tabular}

Note: Data are for urban areas only. Calculations are based on 5 percent return on funds and 2 percent secular income growth. The calculation of benefits under the old system's rule is based on the concept of a base salary, the average amount earned during the 10 years preceding pension benefits.

aThese benefits are at the maximum (70 percent of the base salary).

bThe estimated annuity for the typical woman in the lowest schooling categories falls below the minimum pension. The estimated income is replaced by the minimum pension $(\$ 37,738)$.

'Because the widow's pension is significantly above the minimum pension, it is assumed that the beneficiary would stop receiving the minimum pension (and her own funds would be exhausted).

dEstimated monthly income under the old social security system starts at age 60 . Old system benefits for women in the two upper schooling groups are at the maximum. Benefits are very close to the maximum for the lower schooling categories.

Source: Author estimates based on CASEN 94 data.

also ignore the significant reduction in contribution rates. In order to keep the system solvent, contributions would have to be raised or benefits cut. If the relative benefits of men and women were not affected, gender ratios of benefits before and after the reform can be compared.

Table 5 reports the gender ratio of accumulated contributions and the gender ratio of the present value of benefits for various categories of men and women. The first row in the top panel shows that contributions by women who completed secondary schooling were 43 percent those of men with the same level of schooling. The ratio of accumulated contributions of women relative to men is always less than 1 and typically below 50 percent. (Decomposition of the factors contributing factors to this differential-earlier retirement, lower earnings, less attachment to the labor force-is provided in table 3.) 


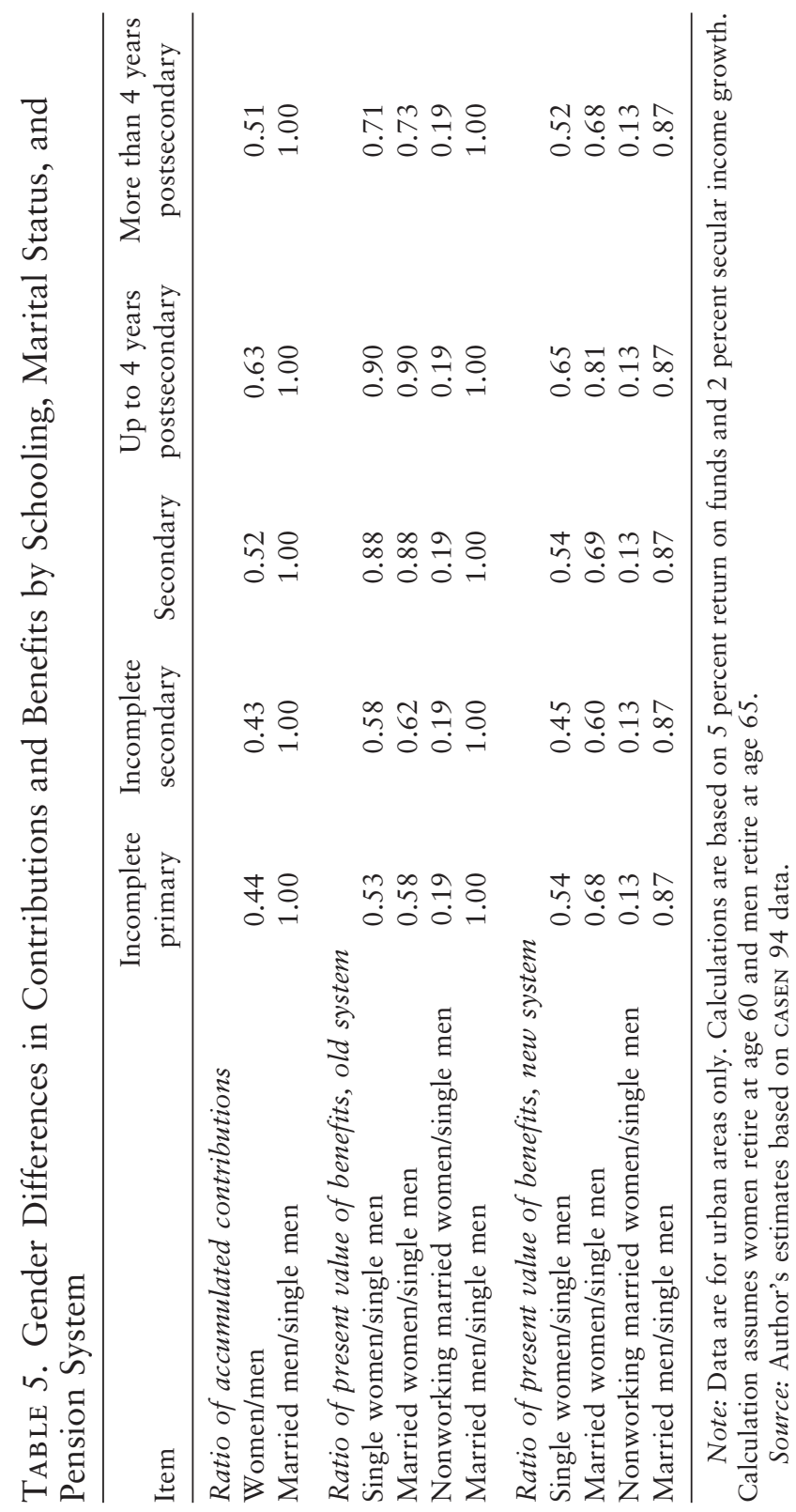


Under the old system's rules, working women with secondary school education drew 88 percent of single men's benefits (table 5). Under the old system there was no strict link between contributions and benefits. The gender disparity between contribution ratios and benefits ratios indicates a significant pro-women bias in the allocation of benefits. The pro-women bias was also regressive: For women with secondary education, the ratio of benefits to contributions was 30 percentage points higher for women than for men, whereas for women with less than secondary schooling, the difference fell to less than 20 percentage points.

Under the new system, single and married working women with secondary school draw 54 percent or 69 percent, respectively, of the benefits that single men obtain (table 5). Benefits are calculated differently for single and married men because married men are required to provide survivor's benefits. Single women are beneficiaries if they have made contributions; married women are beneficiaries if they are either married to a contributor or made contributions themselves.

Contributions and benefits are closely linked, except for two factors. The joint annuities provision requires the redistribution of benefits from husbands to wives; the minimum pension guarantee provides additional benefits from sources outside the system to those who would otherwise draw pensions below a minimum. Single women's benefit ratios are just below the corresponding contributions ratios (see the bottom of table 5), except for the case of low schooling categories, where the minimum pension raises benefits significantly higher than contributions. (The difference between the ratio of contributions and the ratio of benefits in a defined contribution system comes from the cost of annuities. In Chile contributors pay a cost for transforming their accumulated fund into an indexed annuity. This cost is assumed here to be higher for women because they take their annuity for a longer period.) Married women have benefits ratios that exceed their contribution ratios because they receive widows' pensions. For the same reason, for a given ratio of contributions, the ratio of benefits of married men to single men is lower than 1.

Consistent with the fact that the old system was unsustainable, all benefit ratios presented in table 5 are higher than or equal to their corresponding contribution ratios. This includes noncontributing married women who receive a benefit that does not have a counterpart in reduced benefits for married men. This means that the old system contained a significant labor tax component, a significant inflation tax component, or both. In fact, inflation and the system's deficit were part of the picture at the time of reform, which introduces another problem in comparing the benefits between the old and the new systems.

Another feature of the benefit structure of the old system is that women married to men with high earnings received a relatively larger unfounded benefit from the system than women married to men who earned less. This adds a regressive dimension to the old system biases, because contributors finance widows' pensions, which are more generous for widows of men who had had high earnings. 
The old system appears to have had a significant bias in favor of some women and their families, particularly married noncontributor women and married contributors with more than secondary schooling. However, inflation reduced the real value of benefits relative to contributions for all groups. Did the gender bias remain? The answer is empirical because it depends on the impact of inflation on real benefits, which is a function of indexation. Because the system was characterized by a notorious absence of indexation protections and women have longer life expectancies than men, one can say that the real gender bias was smaller than the nominal one. The new system reversed the regressive nature of the gender bias, as it forced each married man to make provisions for his own widow. In addition, it removed the bias against single men, whose funds no longer helped finance widows' pensions.

\section{Who Benefits from Guaranteed Pensions?}

In principle, the state guarantees minimum old age, invalidity, and survival pension benefits to affiliates and their beneficiaries, as long as they are poor and have made contributions for at least 20 years. According to the law, "No one can obtain the state subsidy if the sum of all individual incomes from pensions, rents, and taxable earnings is equal to or higher than the minimum pension." 9 Therefore, unlike access to earned benefits through contributions, access to the guaranteed minimum pensions can be taken away if income-generating conditions change. In fact, qualifying affiliates who also receive the PAsis benefit must give up that pension as soon as the guaranteed minimum benefit is activated. ${ }^{10}$

In practice, the means-testing procedures have not been fully incorporated, and qualification toward the minimum pension is mainly a function of accumulated funds and life expectancy. Putting aside the means testing, an accurate estimate of the number of affiliates who would qualify for the minimum pension at retirement, or for invalidity or survivor's benefits while active, requires longitudinal data on individual contributions.

The typical woman in the lowest schooling category would qualify for the minimum pension under low and high returns; under low returns the typical women in the next two schooling categories would also qualify for the state guarantee. Typical men in the lowest schooling category would qualify for the minimum pension only under low returns, although their accumulated funds are just under the minimum necessary to generate the minimum pension. The mini-

9. Art. 80 , DL 3,500

10. Accidents on the job are covered by insurance, which pays out in proportion to reference salaries. The state guarantee affects people who earn very low salaries, who work few hours or contribute sporadically, or who become incapacitated or die early in their career, leaving a large number of legal survivors. The minimum invalidity pension is paid to affiliates who are declared legally incapacitated, do not qualify for the minimum pension, and fulfill minimum qualifying conditions. There is also a minimum survivor's pension (60 percent of the minimum pension) paid to legal survivors of affiliates who fulfill minimum qualifying conditions. 
mum pension program is thus expected to favor women, as Wagner (1991) and Zurita (1994) have noted.

This exercise in comparative static must be viewed with caution, however, because the relation between earnings and accumulation is affected by the individual's contribution density and the system's rate of return. While the rate of return is a parameter of the system, the density of contributions is a behavioral variable. The current system's rules discourage social security contributions after 20 years worth of accumulated contributions by people whose taxable earnings are low enough to qualify them for the minimum pension. Thus one should expect to observe many people with earnings around the minimum income applying for pensions with exactly 20 years of contributions. ${ }^{11}$

One of the weaknesses of the current rules is that the minimum contribution (on minimum incomes) is not enforced. In particular, if a worker reports parttime income, the minimum contribution becomes in effect lower than the minimum wage. If authorities counted part-time employment (relative to the minimum legal contribution) as partial time, the possibility of making contributions below the legal minimum would be eliminated. The implication is that the number of calendar years of contributions needed to qualify for the minimum pension will be more than 20 for people who work part-time. The effective years of contributions, measured in full-time equivalent minimum earnings, to qualify for the minimum pension will still be 20 years. In addition, authorities can restrict access to the minimum pension by making the program a truly means-tested program. At the very least, information regarding access to widows' pensions should be taken into account to examine eligibility toward continued minimum pension benefits for women.

\section{Summary and Conclusions}

The Chilean pension reform benefited contributors on three fronts: It reduced contributions, it established indexation of benefits, and it made the system sustainable by tying benefits directly to contributions. The reform established a distributive pillar funded directly by the government budget. All these elements reinforce the effect of reducing the tax on labor, encouraging labor force participation and employment. At the same time, the direct link between contributions and benefits required the elimination of cross-subsidies within the system, a source of complex effects on the relative position of women.

It is argued here that the tax reduction effect of social security reform was more pronounced on women. First, under the new system there is no minimum

11. The estimates assume that all workers in a given schooling group are identical in terms of their work patterns. In fact, this is not the case; there is a distribution around the mean. Because some workers have less than 20 years of work, they would not qualify for the minimum pension. Some workers with more than 20 years of work and earnings above the mean may not qualify if their funds are sufficient to fund an annuity above the minimum pension. 
level of contributions to obtain a pension (under the old system contributors with less than 10 years of contributions did not receive pension benefits). Second, the new system allows widows to keep their own pension benefits in addition to their widow's pension, restoring the marginal benefit of own contributions for working women. Third, the reform gives more weight to early years of contributions (as a result of compound interest), rather than the heavy weight given to the last five years in determining the pensionable income under the old system. This change favors women relative to men because women are more likely to hold paid jobs when young and to drop out of the labor force later. Moreover, even if women maintain a significant attachment to the labor force, they tend to have flatter age-earnings profiles than men.

The new system removed three biases associated with funding of survivor's pensions. In Chile's defined-contribution system, survivors' pensions are funded directly by contributors. In the traditional pay-as-you-go system, survivors' pensions were funded from the general system funds. Thus in the traditional system when a rich old man married a young woman a few years before retiring, he would draw a generous pension until his death and bequeath to his widow a generous pension funded from all contributors in the system. In contrast, in the new system, the old man would draw a smaller pension so that after his death the remaining amount would fund a proportional pension for his young widow, who is expected to live many years. Therefore, the new system removed the bias that favored married men (who did not have to make provisions for their widows' pensions) and the bias in favor of widows of rich men who obtained relatively generous pensions financed by all contributors. In addition, according to the rules that apply to the majority of beneficiaries of the old system, if a widow receives her own benefits, she has to choose between those and her widow's pension. In contrast, own pension and survivor's pensions are complementary in the new system. Thus the reform eliminated a bias against married working women.

But the new system also contains its own equity-efficiency tradeoffs, particularly with respect to women. The minimum pension mainly benefits women, given their low rates of pay and limited years of contributions. This study focuses on the work patterns of women affiliates, a subsample of women with a stronger attachment to the labor force. In this group, the typical woman now works about 20 years. Clearly, the new rules will encourage everyone in this group to work to accumulate 20 years of paid work to qualify for the guarantee. The guarantee targets low earners rather than middle-class women. However, once low-earning women (that is, women without substantial postsecondary education) qualify for the minimum pension, they get little if any additional benefit for incremental years of contributions. In effect, they are subject to a heavy implicit marginal tax rate on their labor. The minimum pension effectively becomes a ceiling as well as a floor. Thus the new policy is well designed to keep working women out of poverty in their old age, given their current labor market behavior, but it also maintains that behavior, with transitory labor market attachment, for women with limited education. Although this may be an improvement over the previ- 
ous policy, policymakers may wish to reevaluate this guarantee and tie it more continuously to years of contributions to provide a safety net with even more positive incentive effects.

Perhaps one of the oversights of the Chilean reform was to set women's pension age at 60 . Given the differences in longevity, women would have to save more than men do to obtain the same retirement incomes. In fact, contributing women tend to accumulate less than contributing men because of lower attachment to the labor force and lower earnings than men. Therefore, if not for the minimum pension, women's pensions have to be lower than men's. The expectation of a survivor's pension makes the combined pension benefits of married women higher than that derived solely from own funds. But not all women who work for pay are married or will inherit a pension to complement their incomes in old age.

Overall, the new system is more fiscally sustainable and creates an incentive for greater labor force participation. Women who never enter the labor force are in a more vulnerable position in old age, and this vulnerability is likely to increase as they age. The fact that the Chilean social security reform improved women's incentives to work for pay offers hope for behavioral changes that would reduce women's risk of poverty in old age.

One important lesson to be drawn from this research is that the different work histories of men and women should affect the design of the public pillar and its eligibility requirements. The number of years chosen as a qualifying condition for the minimum pension guarantee is a critical determinant of the gender effects of reform. In Mexico, where affiliates need to contribute for 25 years to qualify for the pubic benefit, and Argentina, where 30 years of contributions are required, the gender impact is probably different, with men instead of women benefiting disproportionately.

\section{REFERENCES}

Baeza Valdés, Sergio, and Raúl Burger Torres. 1995. “Calidad de la Pensiones del Sistema Privado Chileno.” In S. Baeza and F. Margozzini, eds., Quince Años Después: Una Mirada al Sistema Privado de Pensiones. Santiago: Centro de Estudios Públicos.

Davis, E. Phillip. 1998. "Pensions in the Corporate Sector," in Siebert, ed., Redesigning Social Security. Tubingen: Mohr Siebeck.

Edwards, Alejandra Cox. 2000. "A Close Look at Living Standards of Chilean Elderly Men and Women." California State University-Long Beach, Department of Economics.

—. 2001. "Social Security Reform and Women's Pensions.” Working Article Series 17, for World Bank Policy Research Report Gender and Development. World Bank, Washington, D.C.

Edwards, Sebastian, and Alejandra Cox Edwards. 2002. "Social Security Privatization Reform and Labor Markets: The Case of Chile." Economic Development and Cultural Change 50(3):465-89.

Gruber, Jonathan, and David A. Wise, eds. 1999. Social Security and Retirement around the World. Chicago: University of Chicago Press for National Bureau of Economic Research. 
SAFP (Superintendencia de Administradora de Fondos de Pensiones). Various years. Boletín Estadístico (various issues). Santiago.

Wagner, Gert. 1983. "Estudio de la Reforma Previsional: Previsión y Reforma, efectos en la industria y en el país." Universidad Católica, Instituto de Economía (Mayo).

. 1991. "La Seguridad Social y el Programa de Pensión Mínima Garantizada." Estudios de Economía 18(1):35-91.

Zurita, Salvador. 1994. "Minimum Pension Insurance in the Chilean Pension System." Revista de Análisis Económico 9(1):105-26. 